\title{
Thyroid Cancer TNM Finding v6
}

National Cancer Institute

\section{Source}

National Cancer Institute. Thyroid Cancer TNM Finding v6. NCI Thesaurus. Code C60794.

A finding about one or more characteristics of thyroid cancer, following the rules of the

TNM AJCC v6 classification system. 